\title{
Carboxymethylcellulase Activity in Lettuce Seeds Prior to Germination
}

\author{
Alexander D. Pavlista \\ Panhandle Research \& Extension Center, University of Nebraska, Scottsbluff, NE, USA \\ Email: apavlista@unl.edu
}

How to cite this paper: Pavlista, A.D. (2017) Carboxymethylcellulase Activity in Lettuce Seeds Prior to Germination. American Journal of Plant Sciences, 8, 706-719. https://doi.org/10.4236/ajps.2017.84049

Received: January 24, 2017

Accepted: March 13, 2017

Published: March 16, 2017

Copyright $\odot 2017$ by author and Scientific Research Publishing Inc. This work is licensed under the Creative Commons Attribution International License (CC BY 4.0).

http://creativecommons.org/licenses/by/4.0/

\section{(c) (i) Open Access}

\begin{abstract}
Does the endosperm pose a mechanical resistance on embryonic axis (radicle) growth for lettuce seed (achene) germination? To aid answering this question, the cell wall degrading enzyme, carboxymethylcellulase (CMCase) was extracted and assayed from lettuce seeds imbibed for 0 to $12 \mathrm{~h}$, prior to germination. Measuring the loss of viscosity of carboxymethylcellulose, CMCase activity was high in dry seeds, low after $6 \mathrm{~h}$ of imbibition, high after 9 and $10 \mathrm{~h}$, and then reduced again after $12 \mathrm{~h}$. Fractions from Sephadex columns showed CMCase activity in three peaks labeled E1, E2, E3. The greatest change in CMCase activity during imbibition was with E3 (molecular weight of about 40,000 Daltons) and some reduction in E2 (molecular weight about 280,000). The RNA synthesis inhibitor, 6-methyl purine, eliminated CMCase activity when present from 4.5 to $7 \mathrm{~h}$ of imbibition and the protein synthesis inhibitor, cycloheximide, eliminated CMCase activity when present between 5.5 and $9 \mathrm{~h}$. Imbibition in darkness lowered CMCase activity while $15 \mathrm{~min}$ of light at $3.5 \mathrm{~h}$ restored it and $30 \mathrm{~min}$ of far-red light at $3 \mathrm{~h}$ eliminated it. Increasing the imbibition temperature to $35^{\circ} \mathrm{C}$ under light reduced activity while under darkness, activity was eliminated under $24^{\circ} \mathrm{C}$ and $35^{\circ} \mathrm{C}$. CMCase activity was localized in the endosperm surrounding the embryonic axis (micropylar end) of 9 $\mathrm{h}$ imbibed seeds. These observations showed that CMCase was active in degrading the cell wall in the endosperm surrounding the radicle, weakening it, prior to radicle protrusion so that the radicle remains undamaged.
\end{abstract}

\section{Keywords}

Lactuca sativa, Cellulase, Endoglucanase, Cell Wall Breakdown, Skotodormancy, Thermodormancy

\section{Introduction}

The embryo in the lettuce seed is surrounded by an endosperm that is two-cell 
layers thick at the cotyledon end and up to four-cell thick at the radicle or micropylar end [1] [2] [3]. When the endosperm is surgically removed or punctured, germination is promoted [4] [5] [6] [7] suggesting that the endosperm acts as a mechanical restraint [8] [9]. Light microscopy studies on lettuce have observed that the endosperm surrounding the radicle tip undergoes structural changes prior to rupture [10] [11] [12] [13]. Cracking and breakdown of the endosperm at the radicle end, but not laterally, were observed prior to radicle elongation with both light and scanning microscopy [14] [15]. The endosperm around the embryonic axis undergoes autohydrolysis just prior to radicle emergence [16]. From these studies, it was concluded that the breakdown of the endosperm at the micropylar or radicle end is a pre-requisite for germination and occurs prior to the growth of the embryonic axis or radicle [15].

In contrast, the light requirement for germination is reinstated in half seeds and embryos sown in growth inhibiting osmoticum [17]. Their results were interpreted as indicating that light and gibberellin affect the embryo only. However, studies on isolated endosperms and osmotic pressure exerted by salicylhydroxoamic acid showed that stimulation of germination was by weakening of the endosperm at the micropylar region and not by stimulating embryo growth [18]. They also observed that there was no weakening of the endosperm at the lateral cotyledonary regions. A similar study on osmotic pressure and on mechanical strength of the endosperm on tomato seeds came to the same conclusion [19] [20]. This was also concluded from studies on cress [21] and pepper [22]. Light and gibberellins may affect both endosperm weakening and embryo expansion while external osmotic pressures may inhibit only the latter.

The mechanical restraint of the lettuce endosperm may be overcome by two mechanisms: force of the growing embryo against it [17] and an enzymatic weakening of the endosperm at the radicle end [3] [6]. The lettuce seed endosperm when sown in isocyanuric acid is capable of resisting the expansion force of the embryo resulting in embryo expansion without endosperm rupture ("buckling") and protrusion at the cotyledon end or along the side ("atypical germination") [23]. Atypical germination was also reported with cress seeds [24].

Cellulases are able to act on plant cell walls and play a role in loosening and separating cells in the abscission zone in plants [25] [26]. Therefore, cellulases may play a role in endosperm weakening in lettuce seeds. Cellulase activity was observed in lettuce seeds but the study looked after germination and radicle growth [6]. Sanchez et al. [27] studying Datura ferox reported cellulase activity increased prior to endosperm weakening and radicle protrusion after seeds were exposed to red light.

The primary objective of this study was to measure cellulase activity over the time course of imbibition prior to radicle protrusion in lettuce. Molecular weight of the cellulase was estimated, as well as the location of its activity within the seed, and activity under inhibiting conditions of synthesis inhibitors, light and temperature. 


\section{Materials and Methods}

\subsection{Germination Conditions}

Lettuce seeds (Lactuca sativa L.) cultivar Grand Rapids were obtained from Vaughan's Seed Co. (Downer's Grove IL) and vernalized in brown bottles wrapped in $\mathrm{AL}$ foil stored in a desiccator at $4^{\circ} \mathrm{C}$. Prior to use, seeds were acclimated to room temperature and surface sterilized with 5\% Clorox dissolved in $5 \%$ ethanol followed by $70 \%$ ethanol. Seeds were then rinsed four times with sterile distilled water and allowed to air dry. For germination, one gram of seed was placed in each of five sterile Petri dishes containing $10 \mathrm{ml}$ of sterile distilled water and placed in a Sherer-Gillette controlled environment chamber set at $20^{\circ} \mathrm{C}$. Seeds were exposed to continuous white light, a mixture of fluorescent and incandescent light, which was 750 foot-candles at seed level. Germination was scored when the radicle first appeared as seed under a magnification of $30 \times$.

\subsection{Carboxymethylcellulase Extraction}

From 0 to $12 \mathrm{~h}$ of imbibition, a Petri dish with seeds was removed from the environment chamber. One gram seed was ground in $10 \mathrm{ml}$ of cold homogenizing solution consisting of $0.05 \mathrm{M}$ potassium phosphate buffer at $\mathrm{pH} 5.9,0.003 \mathrm{M}$ (0.02\%) $\mathrm{NaN}_{3}$, and $0.025 \mathrm{M} \mathrm{Na}_{2} \mathrm{~S}_{2} \mathrm{O}_{5}$. This coarse ground seed mixture was further homogenized with a drill press with an additional $5 \mathrm{ml}$ of homogenizing solution used to wash the press. The finely ground seed mixture was placed in an ultracentrifuge and spun at $10,000 \mathrm{~g}$ for $10 \mathrm{~min}$. at $4^{\circ} \mathrm{C}$. The supernatant was then re-centrifuged at $37,000 \mathrm{~g}$ for $20 \mathrm{~min}$. at $4^{\circ} \mathrm{C}$. The resulting supernatant was aspirated through a milli-pore filter, $0.22 \mathrm{um}$ pore size. The filtrate was the extraction for assaying carboxymethylcellulase (CMCase) activity. This procedure as well as the assay described in 2.3 were based on that reported for bean and pea [28] [29].

\subsection{Carboxymethylcellulase Assay}

The substrate solution was $1.5 \%$ carboxymethylcellulose (CMC) (7HS or $7 \mathrm{H}$, Hercules Powder Co. dissolved in $0.05 \mathrm{M}$ potassium phosphate buffer ( $\mathrm{pH}$ 5.9) containing $0.003 \mathrm{M}(0.02 \%) \mathrm{NaN}_{3}$. Equal quantities of the enzyme extract and substrate solution were combined and placed in a water bath set at $41^{\circ} \mathrm{C}$. The resulting concentration of $\mathrm{CMC}$ was $0.75 \%$. The $\mathrm{pH}$ of the assay mixture was 5.8 ; preliminary tests determined that optimal $\mathrm{pH}$ was between 5.2 and 6.2. After a 2 -h reaction time, $1 \mathrm{ml}$ aliquots were removed and placed in the measuring chamber of a Wells-Brookfield Rotary Spindle Micro-viscometer kept at $41^{\circ} \mathrm{C}$; preliminary tests determined that optimal temperature was between 40 and $50^{\circ} \mathrm{C}$. Viscosity was measured within $5 \mathrm{~min}$ after mixture was added to chamber. A reaction time longer than $2 \mathrm{~h}$ did not change viscosity loss. In the special case when germination-inhibiting conditions were imposed, a reaction time of $24 \mathrm{~h}$ was used. CMCase activity was expressed as the percent decrease in viscosity ( $-\% \Delta \mu$, reaction time) of enzyme extract/substrate solution compared to the viscosity of boiled enzyme extract plus substrate solution, the no activity control. 
Viscosity of the control was $41 \pm 0.6 \mathrm{cps}$. Data were obtained from five experimental runs, and means with standard errors were calculated for enzyme activity at each time interval of imbibition and graphed.

\subsection{Protein Determination}

Using the micro-biuret method of Goa (1953), protein content of $1 \mathrm{ml}$ of extract plus buffer (1:1) was measured spectrophotometrically at $330 \mathrm{~mm}$ with a Spectronic 20 (Bausch-Lomb) after 20 to $40 \mathrm{~min}$. at room temperature. Bovine serum albumin was used as a standard. Protein content was calculated from a standard curve obtained from bovine serum albumin.

\subsection{Molecular Weight Estimation}

Sephadex columns, G-100 and G-200, were prepared with 0.05 M potassium phosphate buffer at $\mathrm{pH} 5.9$ plus $0.003 \mathrm{M} \mathrm{NaN}_{3}$, and maintained at $8^{\circ} \mathrm{C}$. The column bed was $200 \mathrm{ml}$ and the flow rates were 4 and $2.5 \mathrm{ml} / \mathrm{cm}^{2}-\mathrm{h}$ for G-100 and G-200 columns, respectively. Protein standards were aldolase, ovalbumin, chymotrypsinogen $\mathrm{A}$, ribonuclease $\mathrm{A}$, and bovine serum albumin (Pharmacia Calibration Kit). Two ml CMCase extracts were applied to the column through a 4 -way valve followed by $1 \mathrm{ml}$ of $10 \%$ sucrose. Sixty drop fractions were collected and assayed for CMCase activity. Viscosity was measured $24 \mathrm{~h}$ after reaction time and expressed as $\% \Delta \mu, 24 \mathrm{~h}$. The partitioning coefficient $\left(\mathrm{K}_{\mathrm{av}}\right)$ of active fractions was calculated and plotted against the log molecular weight as determined by the standards. Molecular weights in Daltons were estimated from the plots.

\subsection{Inhibitors}

Lettuce seeds imbibed in either sterile distilled water, cycloheximide $(\mathrm{CH})$ at 100 $\mathrm{mg} / \mathrm{l}$ or 6-methyl purine (MP) at $67 \mathrm{mg} / \mathrm{l}$ for varying periods in the first $9 \mathrm{~h}$ of imbibition. In the case of 6-methyl purine, seeds were punctured with a $22 \mathrm{G}$ syringe needle at the cotyledonary end to allow penetration. Between treatments of inhibitor and sterile distilled water, seeds were rinsed with the appropriate next medium and returned to Petri dishes containing fresh treatment. CMCase was extracted and assayed after the $9 \mathrm{~h}$ imbibition period. Data from three replicated trials were averaged with standard errors and treatments were compared least significant differences at $95 \%$ confidence level.

\subsection{Light and Temperature Variations}

To test the effects of light, seeds were imbibed in water for $9 \mathrm{~h}$ under three lighting conditions: continuous darkness, darkness with a 15-min white light exposure at 750 foot-candles after $3.5 \mathrm{~h}$ of darkness, and a $1 \mathrm{~h}$ exposure to far-red light after $3 \mathrm{~h}$ of darkness. Far-red light exposure was accomplished by using two incandescent 150 watt lamps underlaid with a $3 \mathrm{~mm}$ thick slab of Rohm-Haas 2025 black plexiglass and $3 \mathrm{~cm}$ of water. The effect of germination temperature was determined by germinating seeds under $20^{\circ} \mathrm{C}, 24^{\circ} \mathrm{C}$ and $35^{\circ} \mathrm{C}$ 
in continuous white light and continuous darkness. CMCase was extracted and assayed after the $9 \mathrm{~h}$ imbibition period. Data from three replicated trials were averaged with standard errors and treatments were compared least significant differences at $95 \%$ confidence level.

\subsection{Seed Parts Separation}

Lettuce seeds imbibed in water for 1 and $9 \mathrm{~h}$ under standard conditions were dissected into three parts. The radicle end comprised one-third of the seed, and the cotyledonary end was the other two-thirds. The radicle end was further separated into the embryonic axis and the endosperm surrounding it. Separation of the cotyledons from the surrounding endosperm even after $1 \mathrm{~h}$ of imbibition was not successful without severely damaging both. One gram of seed was dissected into these parts, and CMCase was extracted, fractionated on a Sephadex G-100 column, and assayed as described earlier. Data from three replicated trials were averaged with standard errors and treatments were compared least significant differences at 95\% confidence level.

\section{Results}

\subsection{Imbibition and Germination}

Seed imbibition was rapid upon water exposure and reached maximum after three hours. Seed germination began after imbibing for $12 \mathrm{~h}$ with the rate of germination highest at $15 \mathrm{~h}-16 \mathrm{~h}$ after imbibition, reaching $74 \%$ and $78 \%$ germination after 18 and $24 \mathrm{~h}$, respectively (data not shown).

\subsection{CMCase during Imbibition}

CMCase was extracted and assayed for seeds imbibed for $0,2,4,6,8,9,10$, and $12 \mathrm{~h}$. Activity fluctuated during imbibition. Activity was present in dry seed as evidenced by the loss of viscosity of CMC and decreased to a minimum after $6 \mathrm{~h}$ of imbibition (Figure 1). After $6 \mathrm{~h}$ imbibition, CMCase activity increased to a maximum after 9 and $10 \mathrm{~h}$ of imbibition followed by lower activity at $12 \mathrm{~h}$ (Figure 1) at the onset of germination. Protein content was measured after 0, 6, 9 , and $12 \mathrm{~h}$ of imbibition and remained constant at $2.3 \pm 0.2 \mathrm{mg} / \mathrm{ml}$ extract. Three CMCase activity peaks, labeled as E1, E2 and E3, were identified. All three appeared in seeds imbibed for 0 and $9 \mathrm{~h}$ (Figure 2). In seeds imbibed for 6 and $12 \mathrm{~h}, \mathrm{E} 1$ dominated although some E2 and a trace of E3 were also present. These activity peaks corresponded to molecular weights in Dalton of 480,000 for E1, 280,000 for E2, and 40,000 for E3 as determined using Sephadex column chromatography (data not shown).

\subsection{Synthesis Inhibitors}

CMCase activity in seeds imbibed in water for $9 \mathrm{~h}$ showed a $20 \%$ decrease in viscosity of $0.75 \% \mathrm{CMC}$ as in Figure 1. However, when imbibed in $\mathrm{CH}$, a protein synthesis inhibitor, for $9 \mathrm{~h}$, very little activity was detected and there was no germination (Table 1). When seeds were imbibed in $\mathrm{CH}$ for the first $5.5 \mathrm{~h}$ and 
$\%$

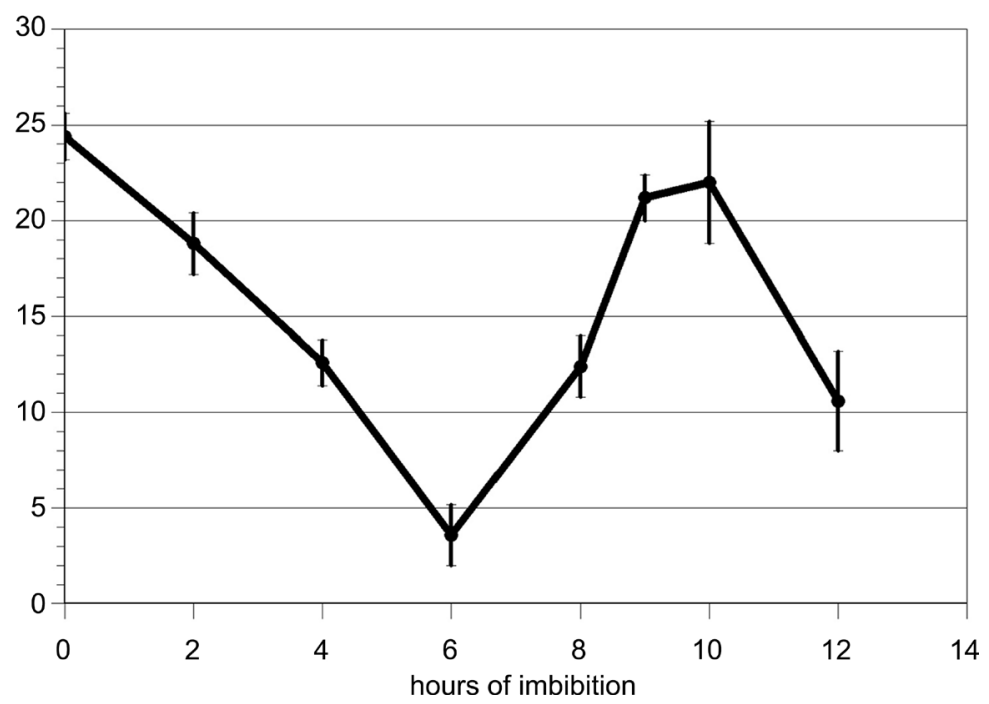

Figure 1. Carboxymethylcellulase activity in lettuce seeds prior to germination, i.e., radicle protrusion, expressed as the $\%$ decrease in viscosity of $0.75 \%$ carboxymethylcellulose after a $2 \mathrm{~h}$ reaction time with extract based on $1 \mathrm{~g}$ of dry seeds. Vertical bars represent standard errors based on five to nine replications.
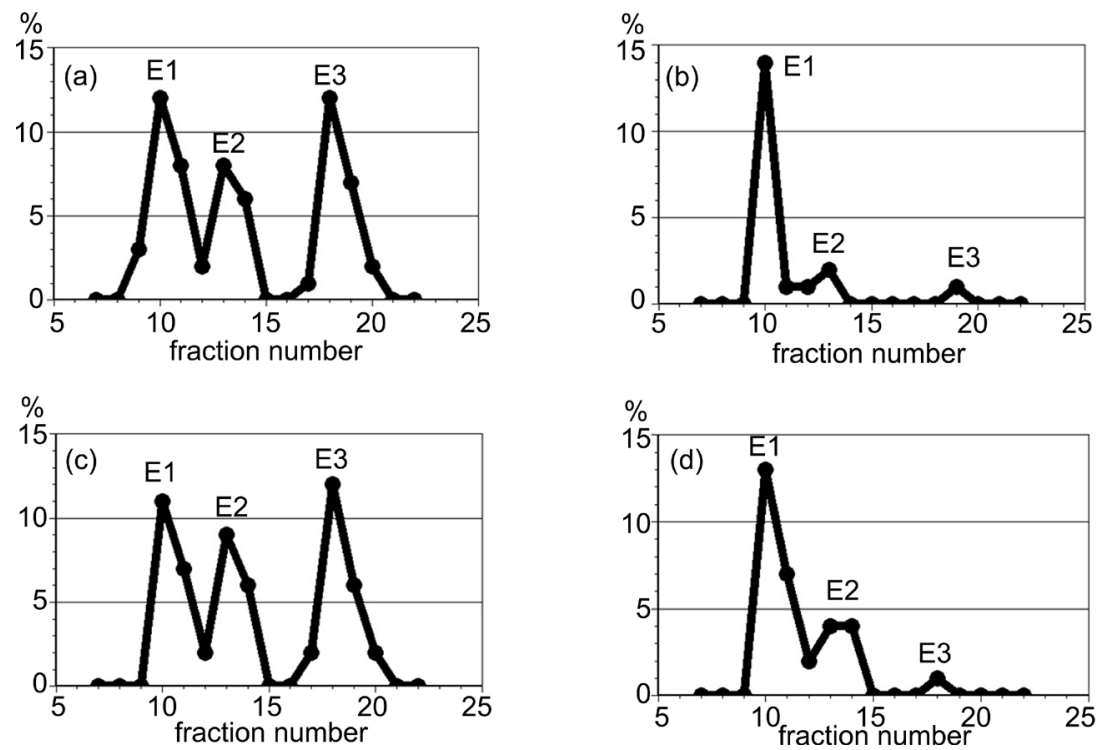

Figure 2. Carboxymethylcellulase activity in 120-drop fractions from a Sephadex G-100 column. CMCase extracts were obtained from lettuce seeds imbibed for a. 0 h, b. 6 h, c. 9 $\mathrm{h}$, and $12 \mathrm{~h}$, and activity expressed as the \% decrease in viscosity of $0.75 \%$ carboxymethylcellulose after a $2 \mathrm{~h}$ reaction time with extract based on $1 \mathrm{~g}$ of dry seeds based on three replications.

then transferred to water, CMCase activity from $9 \mathrm{~h}$ seed was the same as that from water only imbibed seed and seeds germinated albeit delayed compared to water controls (Table 1). When seeds were water-imbibed for $5.5 \mathrm{~h}$ and then placed in $\mathrm{CH}$, there was no CMCase activity and no germination as if seeds were in $\mathrm{CH}$ continuously (Table 1 ). When seeds were imbibed in MP, a RNA synthesis inhibitor, for $9 \mathrm{~h}$, there was CMCase activity as if in water even though there 
Table 1. Carboxymethylcellulase activity in 9-h imbibed lettuce seeds as affected by synthesis inhibitors.

\begin{tabular}{|c|c|c|c|c|c|c|}
\hline \multicolumn{4}{|c|}{ Hour of Imbibition } & $\begin{array}{l}\text { CMCase } \\
\text { activity }^{1}\end{array}$ & \multicolumn{2}{|c|}{$\begin{array}{l}\text { Normal germination } \\
\text { (atypical germination }^{2} \text { ) }\end{array}$} \\
\hline $0-5.5$ & & $5.5-9$ & & $\begin{array}{c}-\% \Delta \mu \text { after } 24 \\
\mathrm{~h}\end{array}$ & $\begin{array}{c}\% \text { after } 48 \\
\text { h }\end{array}$ & $\begin{array}{c}\% \text { after } 96 \\
\text { h }\end{array}$ \\
\hline water & & water & & $20 \mathrm{~A}^{3}$ & 84 & 95 \\
\hline $\mathrm{CH}^{4}$ & & $\mathrm{CH}$ & & $3 \mathrm{C}$ & 0 & 0 \\
\hline $\mathrm{CH}$ & & water & & $20 \mathrm{~A}$ & 0 & 73 \\
\hline water & & $\mathrm{CH}$ & & $2 \mathrm{C}$ & 0 & 0 \\
\hline $\mathrm{MP}^{4}$ & & MP & & $21 \mathrm{~A}$ & 5 & 9 \\
\hline $\mathrm{MP}^{5}$ & & MP & & $3 \mathrm{C}$ & 0 & 0 \\
\hline $\mathrm{MP}^{5}$ & & water & & $5 \mathrm{BC}$ & $39(6)$ & 55 (11) \\
\hline water ${ }^{5}$ & & MP & & $9 \mathrm{~B}$ & $8(3)$ & $9(3)$ \\
\hline $0-4.5$ & $4.5-7$ & & & & & \\
\hline water $^{3}$ & MP & & water & $2 \mathrm{C}$ & 0 & 0 \\
\hline $\mathrm{MP}^{3}$ & water & & MP & $18 \mathrm{~A}$ & $49(2)$ & $64(4)$ \\
\hline
\end{tabular}

${ }^{1}$ Carboxymethylcellulase activity expressed as the $\%$ decrease in viscosity of $0.75 \%$ carboxymethylcellulose after a $24 \mathrm{~h}$ reaction time based on extraction from $1 \mathrm{~g}$ of dry seeds imbibed. ${ }^{2}$ Atypical germination, i.e., protrusion from cotyledonary end, observed and presented in parenthesis as described in Pavlista and Haber [23]. ${ }^{3}$ Numbers in each column followed by different letters are significantly different at the $95 \%$ confidence level using the t-test on three replicated tests. ${ }^{4} \mathrm{CH}=$ cycloheximide at $100 \mathrm{mg} / \mathrm{l}, \mathrm{MP}=6$-methyl purine at $67 \mathrm{mg} / \mathrm{l} .{ }^{5}$ Seeds were punctured with a needle at cotyledonary end to allow penetration.

was little germination (Table 1). Since MP may not be entering the seed sufficiently to affect CMCase, seeds were punctured with a thin needle at the cotyledonary end to allow greater penetration. Now, there was little if any CMCase activity (Table 1). When punctured seeds were first placed in MP and transferred into water after $5.5 \mathrm{~h}$, there still was no CMCase activity although there was delayed germination as well as some atypical germination at the puncture. When the reverse was performed, i.e., water then MP, there was a little CMCase activity and some, $>10 \%$, normal germination (Table 1 ). When seeds were imbibed in MP for $4.5 \mathrm{~h}$, transferred to water from 4.5 to $7 \mathrm{~h}$ of imbibition, and returned to MP before extraction at $9 \mathrm{~h}$ of imbibition, CMCase activity remained and germination occurred although delayed (Table 1). When the reverse was performed and seeds were initially in water, transferred to MP at $4.5 \mathrm{~h}$ of imbibition, and then returned to water at $7 \mathrm{~h}, \mathrm{CMCase}$ activity was eliminated as was germination (Table 1).

\subsection{Germination Lighting and Temperature}

Under the standard conditions of $20^{\circ} \mathrm{C}$ and continuous white light, CMCase activity of $9 \mathrm{~h}$ water-imbibed seeds was that reported in Figure 1; endosperm cracking, as described in Pavlista and Valdovinos, [14], appeared after $12 \mathrm{~h} \mathrm{im-}$ bibition, and germination was $75 \%$ after $24 \mathrm{~h}$. Imbibing in continuous darkness resulted in reduced enzyme activity at $9 \mathrm{~h}$ and lower germination (Table 2). When continuous darkness is interrupted with white light for $15 \mathrm{~min}$ after $3.5 \mathrm{~h}$ of imbibition, the results were similar to that of continuous white light (Table 
2). On the other hand, when darkness was interrupted with $1 \mathrm{~h}$ of far-red light from 3 to $4 \mathrm{~h}$ of imbibition, CMCase activity nearly disappears as well as very low endosperm cracking and germination (Table 2). Raising the germination temperature from $20^{\circ} \mathrm{C}$ to $24^{\circ} \mathrm{C}$ under white light had no effect on CMCase activity or germination, but raising the temperature further to $35^{\circ} \mathrm{C}$ under white light reduced CMCase activity and eliminated germination (Table 2). When seeds were placed at $24^{\circ} \mathrm{C}$ or $35^{\circ} \mathrm{C}$ in darkness, CMCase activity, endosperm cracking and germination were very low at $24^{\circ} \mathrm{C}$, and they were eliminated at $35^{\circ} \mathrm{C}$ ('Table 2).

\subsection{CMCase Localization}

In seeds imbibed for 0 - $1 \mathrm{~h}$, CMCase was present throughout the seed, the radicle and the cotyledon ends (Table 3 ). However, separation on a Sephadex column showed that, although E1 and E2 were present in both ends, peak E3 was present only at the radicle end (data not shown). In 9 - $10 \mathrm{~h}$ imbibed seeds, CMCase activity was found in the radicle end but not in the cotyledon end. Furthermore, the enzyme activity was in the endosperm surrounding the embryonic axis but not in the embryonic axis itself (Table 3). Therefore, the endosperm surrounding the axis of 9 - $10 \mathrm{~h}$ imbibed seeds contained the CMCase activity.

\section{Discussion}

\subsection{Timing of Activity}

CMCase activity was present in dry lettuce seeds and decreased to a minimum

Table 2. Carboxymethylcellulase activity in 9-h imbibed lettuce seeds as affected by germination temperature and light.

\begin{tabular}{|c|c|c|c|c|}
\hline Temperature & $\begin{array}{c}\text { Light } \\
\text { exposure }\end{array}$ & CMCase activity $^{1}$ & Endosperm cracking ${ }^{2}$ & Germination \\
\hline${ }^{\circ} \mathrm{C}$ & & $-\% \Delta \mu$ at $24 \mathrm{~h}$ & $\%$ after $12 \mathrm{~h}$ & $\%$ after $24 \mathrm{~h}$ \\
\hline 20 & $\begin{array}{l}\text { continuous } \\
\text { white light }^{3}\end{array}$ & $20 \mathrm{~A}^{4}$ & $47 \mathrm{~A}$ & $75 \mathrm{~A}$ \\
\hline 20 & $\begin{array}{c}\text { continuous } \\
\text { darkness }\end{array}$ & $10 \mathrm{~B}$ & $50 \mathrm{~A}$ & $48 \mathrm{~B}$ \\
\hline 20 & $\begin{array}{c}\text { darkness }+0.25 \mathrm{~h} \\
\text { white at } 3.5 \mathrm{~h}\end{array}$ & $21 \mathrm{~A}$ & $50 \mathrm{~A}$ & $74 \mathrm{~A}$ \\
\hline 20 & $\begin{array}{l}\text { darkness }+1 \mathrm{~h} \\
\text { far-red at } 3 \mathrm{~h}\end{array}$ & $2 \mathrm{C}$ & $8 \mathrm{C}$ & $15 \mathrm{C}$ \\
\hline 24 & $\begin{array}{l}\text { continuous } \\
\text { white light }\end{array}$ & $22 \mathrm{~A}$ & $51 \mathrm{~A}$ & $70 \mathrm{~A}$ \\
\hline 24 & $\begin{array}{l}\text { continuous } \\
\text { darkness }\end{array}$ & $4 \mathrm{C}$ & $9 \mathrm{C}$ & $23 \mathrm{C}$ \\
\hline 35 & $\begin{array}{l}\text { continuous } \\
\text { white light }\end{array}$ & $11 \mathrm{~B}$ & $40 \mathrm{~B}$ & $0 \mathrm{D}$ \\
\hline 35 & $\begin{array}{l}\text { continuous } \\
\text { darkness }\end{array}$ & $1 \mathrm{C}$ & $0 \mathrm{C}$ & $0 \mathrm{D}$ \\
\hline
\end{tabular}

${ }^{1}$ Carboxymethylcellulase activity expressed as the \% decrease in viscosity of $0.75 \%$ carboxymethylcellulose after a $24 \mathrm{~h}$ reaction time based on extraction from $1 \mathrm{~g}$ of dry seeds imbibed. ${ }^{2}$ Endosperm cracks at the radicle end as seen using scanning electron microscopy as described in Pavlista and Valdovinos [14]. ${ }^{3}$ White light $=750 \mathrm{ft}$-candles at seed level. ${ }^{4}$ Numbers in each column followed by different letters are significantly different at the $95 \%$ confidence level using the t-test on three replicated tests. 
Table 3. Localization of carboxymethylcellulase activity in 0 to $1 \mathrm{~h}$ imbibed seeds versus in 9 to $10 \mathrm{~h}$ imbibed seeds.

\begin{tabular}{cccc}
\hline & & \multicolumn{2}{c}{ CMCase activity $^{1},-\% \Delta \mu$ after $2 \mathrm{~h}$} \\
\hline \multirow{2}{*}{ Radicle end } & Seed part & Imbibed $0-1 \mathrm{~h}$ & Imbibed $9-10 \mathrm{~h}$ \\
& One-third of seed & 14 & $20 \mathrm{~A}^{2}$ \\
& Embryonic axis & 8 & $1 \mathrm{~B}$ \\
Cotyledon end & Endosperm & 14 & $21 \mathrm{~A}$ \\
\hline
\end{tabular}

${ }^{1}$ Carboxymethylcellulase activity expressed as the \% decrease in viscosity of $0.75 \%$ carboxymethylcellulose after a $2 \mathrm{~h}$ reaction time based on extraction from $1 \mathrm{~g}$ of dry seeds imbibed. ${ }^{2}$ Numbers in each column followed by different letters are significantly different at the $95 \%$ confidence level using the $t$-test on three replicated tests.

by $6 \mathrm{~h}$ of imbibition followed by a sharp increase and a maximum at 9 and $10 \mathrm{~h}$ of imbibition, three hours prior to the first signs of radicle elongations [14]. This observation corresponds to the loosening of the endosperm, indicative of weakening, after $9 \mathrm{~h}$ of imbibition reported by Guedes et al. [30]. Psaras and Paragamian [12] [13] reported that there was no structural changes in the lettuce endosperm during the first eight hours of imbibition, but at $9 \mathrm{~h}$ after imbibition, the endosperm cells, only at the micropylar region, showed structural changes. There was no change in the endosperm cells in the lateral or cotyledonary regions. The time course of CMCase activity agreed with the timing of endosperm weakening and radicle protrusion.

\subsection{Synthesis Inhibition}

RNA and protein are required for lettuce seed germination [31]. Although all enzymes synthesized de novo during the first $9 \mathrm{~h}$ of imbibition would be inhibited by synthesis inhibitors and many would affect germination, the purpose of adding inhibitors was to learn whether enzymes that breakdown of CMC would be among them. Therefore, to determine whether the peak in CMCase activity that occurred after $9 \mathrm{~h}$ of imbibition could be prevented by the addition of an RNA synthesis inhibitor, MP, and/or a protein synthesis inhibitor, $\mathrm{CH}$, seeds were exposed to these inhibitors at different times. Exposure to MP between 4.5 and $7 \mathrm{~h}$ after starting imbibition was sufficient to prevent the $9 \mathrm{~h}$ activity peak and germination. When MP was not present in that time period but before and after it, the activity peak was not prevented nor was radicle growth prevented. This indicated that the mRNA for CMCase was synthesized between 4.5 and $7 \mathrm{~h}$ of imbibition. Exposure to $\mathrm{CH}$ between 5.5 and $9 \mathrm{~h}$ of imbibition prevented the CMCase activity peak at $9 \mathrm{~h}$ and prevented germination. This indicated that CMCase was synthesized between 5.5 and $9 \mathrm{~h}$, just following the synthesis of its mRNA.

\subsection{Light and Temperature}

Light promotes lettuce seed germination while imbibing in darkness promotes a 
secondary dormancy (skotodormancy) [32]. Seeds sown in darkness showed a lower CMCase activity at $9 \mathrm{~h}$ of imbibition as well as reduced germination in the study reported here. However a $15 \mathrm{~min}$ exposure to light after $3.5 \mathrm{~h}$ of imbibition was sufficient to achieve the CMCase activity $9 \mathrm{~h}$ peak. The CMCase activity at 9 $\mathrm{h}$ under light was negated by a one hour exposure to far-red light, showing a phytochrome effect on the enzyme. Raising the imbibition temperature to $24^{\circ} \mathrm{C}$ in light had no effect but in darkness, CMCase activity at $9 \mathrm{~h}$ was greatly reduced as well as germination and endosperm weakening. A high temperature of $35^{\circ} \mathrm{C}$ is often used to study thermodormancy in lettuce seeds [10] [14] [15] [30] so the purpose of using this temperature was to determine whether CMCase activity was still present under this condition. Raising the temperature further to $35^{\circ} \mathrm{C}$, thermodormancy induction, CMCase activity was reduced and germination inhibited. These indicate a close relation between CMCase activity at $9 \mathrm{~h}$ of imbibition to skotodormancy and thermodormancy.

\subsection{Enzyme Forms}

To determine the molecular weight of CMCase at different times of imbibition, extracts at different times of imbibition were applied to Sephadex chromatography columns. Unexpectantly, three molecular-weight-based CMCase activity peaks, labeled E1, E2 and E3, were measured. E1 was the heaviest and E3 the lightest. E1 activity did not change during imbibition. However, E2 and especially the lightest E3 activity changed over time. E2 and E3 activities were greatly reduced at 6 and $12 \mathrm{~h}$ of imbibition while being present at $9 \mathrm{~h}$ to the same degree as in dry seeds. In view of the study on synthesis inhibitors, this indicated that E2 and E3 were degraded between 0 and $6 \mathrm{~h}$, and after $10 \mathrm{~h}$ of imbibition, and synthesized de novo prior to $9 \mathrm{~h}$.

\subsection{Enzyme Localization}

For CMCase to play a major role in endosperm weakening at the radicle end, it is critical for the enzyme to be present in the endosperm there. This study observed that in dry seeds CMCase was present throughout the seed, both in the embryo as well as in the endosperm surrounding it. However, in seeds imbibed for $9-10 \mathrm{~h}$, CMCase activity was measured only in the endosperm in the third of the seed surrounding the radicle. This showed that the enzyme was in the right place at the right time.

\subsection{Other Enzymes}

Other enzymes have also been studied for the role in lettuce seed germination. Since the principle carbohydrate component in the endosperm is mannose [33], emphasis was placed on the activity of endo- $\beta$-mannase. However in lettuce seeds, mannase activity increased only after germination [34]. Although mannase activity was stimulated by gibberellins and red light, it increased after radicle emergence [35]. There was no detectable reserve mobilization during imbibition [36]. Furthermore, mannase activity arose from the cotyledons [37]. The 
conclusion from these studies was that endo- $\beta$-mannase was involved in degrading mannan as a nutrient source for early seedling growth of lettuce [34]. Another enzyme studies was $\alpha$-galactosidase in lettuce seeds. Although activity of this enzyme was increased by red light prior to radicle emergence, after about $5 \mathrm{~h}$ of imbibition, and there was no activity increase in darkness, activity increased even when seeds were dormant [38]. Besides that this enzyme increased without germination, it is also was observed in both the cotyledons and embryo [39]. These authors concluded that this enzyme was not directly correlated with germination and endosperm weakening. Sodium dichloroisocyanurate had been reported to induce atypical germination of lettuce seeds [23]. In a study on $\alpha$-L-arabinofuranosidase recently published, Liu et al. [40] reported that this enzyme was suppressed by sodium dichloroisocyanurate and was partially responsible for atypical germination. Arabinofuranosidase activity was present in dry seed and in the endosperm at the micropylar region (radicle end). Activity does not change during the first $6 \mathrm{~h}$ of imbibition but showed a slight increase between 6 and $14 \mathrm{~h}$ of imbibition, prior to germination. The authors concluded that this enzyme may play a role in endosperm weakening. The timing of activity of this enzyme was similar to that reported here for cellulase.

\section{Conclusion}

Endosperm weakening at the radicle end (micropylar region) is a pre-requisite for normal lettuce seed germination [23]. CMCase plays a major role in this weakening. Evidence supporting this conclusion is: 1) its synthesis de novo prior to endosperm collapse and radicle elongation [14],2) its inhibition by darkness and far-red light, and by raised imbibition temperature, and 3) its location in the radicle end of the endosperm prior to radicle elongation.

\section{References}

[1] Borthwick, H.A. and Robbins, W.W. (1928) Lettuce Seed and Germination. Hilgardia, 3, 275-305. https://doi.org/10.3733/hilg.v03n11p275

[2] Foard, D.E. and Haber, A.H. (1966) Mitosis in Thermodormant Lettuce Seeds with Reference to Histological Location, Localized Expansion, and Seed Storage. Planta, 71, 160-170. https://doi.org/10.1007/BF00390135

[3] Jones, R.L. (1974) The Structure of the Lettuce Endosperm. Planta, 121, 133-146. https://doi.org/10.1007/BF00388752

[4] Evenari, M. and Neumann, G. (1952) The Germination of Lettuce Seed. II. The Influence of Fruit Coat, Seed Coat and Endosperm upon Germination. Bulletin of the Research Council of Israel, 2, 75-78.

[5] Ikuma, H. and Thimann, K.V. (1959) Photosensitive Site in Lettuce Seeds. Science, 130, 568-569. https://doi.org/10.1126/science.130.3375.568

[6] Ikuma, H. and Thimann, K.V. (1963) The Role of the Seed Coats in Germination of Photosensitive lettuce Seeds. Plant \& Cell Physiology, 4, 169-185.

[7] Speer, H.L. (1974) Some Aspects of the Function of the Endosperm during the Germination of Lettuce Seeds. Canadian Journal of Botany, 52, 1117-1131. https://doi.org/10.1139/b74-141

[8] Amen, R.D. (1968) A Model of Seed Dormancy. Botanical Review, 34, 1-31. 
https://doi.org/10.1007/BF02858619

[9] Koller, D., Mayer, A.M., Poljakoff-Mayber, A. and Klein, S. (1962) Seed Germination. Annual Review of Plant Biology, 13, 437-464.

https://doi.org/10.1146/annurev.pp.13.060162.002253

[10] Georghiou, K., Psaras, G. and Mitrakos, K. (1983) Lettuce Endosperm Structural Changes during Germination under Different Light, Temperature, and Hydration Conditions. Botanical Gazette, 144, 207-211. https://doi.org/10.1086/337362

[11] Psaras, G., Georghiou K. and Mitrakos, K. (1981) Red-Light-Induced Endosperm Preparation for Radicle Protrusion of Lettuce Embryos. Botanical Gazette, 142, 13 18. https://doi.org/10.1086/337190

[12] Psaras, G. (1984) On the Structure of Lettuce (Lactuca sativa L.) Endosperm during Germination. Annals of Botany, 54, 187-194. https://doi.org/10.1093/oxfordjournals.aob.a086782

[13] Psaras, G.K. and Paragamian, K. (1984) Structural Alterations in Isolated Endosperms of lactuca sativa L. Achenes. Journal of Plant Physiology, 117, 93-96. https://doi.org/10.1016/S0176-1617(84)80020-6

[14] Pavlista, A.D. and Valdovinos, J.G. (1978) Changes in the Surface Appearance of the Endosperm during Lettuce Achene Germination. Botanical Gazette, 139, 171 179. https://doi.org/10.1086/336984

[15] Sung, Y., Cantliffe, D.J., Nagata, R.T. and Nascimento, W.M. (2008) Structural Changes in Lettuce Seed during Germination at High Temperature Altered by Genotype, Seed maturation Temperature, and Seed Priming. Journal of the American Society for Horticultural Science, 133, 300-311.

[16] Dutta, S., Bradford, K.J. and Nevins, D.J. (1994) Cell-Wall Autohydrolysis in Isolated Endosperms of Lettuce (Lactuca sativa L.). Plant Physiology, 104, 623-628. https://doi.org/10.1104/pp.104.2.623

[17] Carpita, N.C., Nabors, M.W., Ross, C.W. and Petretic, N.L. (1979) The Growth Physics and Water Relations of Red-light-induced Germianation in Lettuce Seeds. III. Changes in the Osmotic and Pressure Potential in the Embryonic Axes of Redand Far-red-treated Seeds. Planta, 144, 217-224. https://doi.org/10.1007/BF00388762

[18] Brooks, C.A. and Mitchell, C.A. (1988) Effect of Salicylhydroxamic Acid on Endosperm Strength and Embryo Growth of Lactuca sativa L. cv Waldmann's Green Seeds. Plant Physiology, 86, 826-829. https://doi.org/10.1104/pp.86.3.826

[19] Groot, S.P.C. and Karssen, C.M. (1987) Gibberellins Regulate Seed Germination in Tomato by Endosperm Weakening: A Study with Gibberellin-Deficient Mutants. Planta, 17, 525-531. https://doi.org/10.1007/BF00392302

[20] Ni, B.-R. and Bradford, K.J. (1993) Germination and Dormancy of Abscisic Acidand Gibberelliin-Deficient Mutant Tomato (Lycopersicon esculentum) Seeds. Sensitivity of Germination to Abscisic Acid, Gibberellin, and Water Potential. Plant Physiology, 101, 607-617. https://doi.org/10.1104/pp.101.2.607

[21] Muller, K., Tintelnot, S. and Leubner-Metzger G. (2006) Endosperm-Limited Brassicaceae Seed Germination: Abscisic Acid Inhibits Embryo-Induced Endosperm Weakening of Lepidium sativum (Cress) and Endosperm Rupture of Cress and Arabidopsis thaliana. Plant \& Cell Physiology, 47, 864-877. https://doi.org/10.1093/pcp/pcj059

[22] Watkins, J.T. and Cantliffe, D.J. (1983) Mechanical Resistance of the Seed Coat and Endosperm during Germination of Capsicum annuum at Low Temperature. Plant Physiology, 72, 146-150. https://doi.org/10.1104/pp.72.1.146

[23] Pavlista, A.D. and Haber, A.H. (1970) Embryo Expansion without Protrusion in 
Lettuce Seeds. Plant Physiology, 45, 636-637. https://doi.org/10.1104/pp.46.4.636

[24] Muller, K., Linkies, A., Vreeburg, A.M., Fry, S.C., Krieger, L. and Leubner-Metzger, G. (2009) In Vivo Cell Wall Loosening by Hydroxy Radicles during Cress Seed Germination and Elongation Growth. Plant Physiology, 150, 1855-1865. https://doi.org/10.1104/pp.109.139204

[25] Lieberman, S.J., Valdovinos, J.G. and Jensen, T.E. (1982) Ultrastructure Localization of Cellulase in Abscission Cells of Tobacco Flower Pedicels. Botanical Gazette, 143, 32-40. https://doi.org/10.1086/337268

[26] Van Doorn, W.G. and Stead, A.D. (1997) Abscission of Flowers and Floral Parts. Journal of Experimental Botany, 48, 821-837. https://doi.org/10.1093/jxb/48.4.821

[27] Sanchez, R.A., De Miguel, L. and Mercuri, O. (1986) Phytochrome Control of Cellulase Activity in Datura ferox L. Seeds and Its Relationship with Germination. Journal of Experimental Botany, 37, 1574-1580. https://doi.org/10.1093/jxb/37.10.1574

[28] Byrne, H., Christou, N.V., Verma, D.P.S. and Maclachlan, G.A. (1975) Purification and Characterization of Two Cellulases in Auxin-Treated Pea. Journal of Cell Biolo$g y, 69,97-105$.

[29] Lew, F.T. and Lewis, L.N. (1974) Purification and Properties of Cellulases from Phaseolus vulgaris. Phytochemistry, 13, 1359-1366. https://doi.org/10.1016/0031-9422(74)80292-X

[30] Guedes, A.C., Cantliffe, D.J. and Nell, T.A. (1981) Morphological Changes during Lettuce Seed Priming and Subsequent Radicle Development. Journal of the American Society for Horticultural Science, 106, 121-126.

[31] Khan, A.A. (1966) Inhibition of Lettuce Seed Germination and Seedling Growth by Antimetabolites of Nucleic Acids, and Reversal by Nucleic Acid Precursors and Gibberellic Acid. Planta, 68, 83-87. https://doi.org/10.1007/BF00385373

[32] Bewley, J.D. (1980) Secondary Dormancy (Skotodormancy) in Seeds of Lettuce (Lactuca sativa cv. Grand Rapids) and Its Release by Light, Gibberellic Acid and Benzyladenine. Physiologia Plantarum, 49, 277-280. https://doi.org/10.1111/j.1399-3054.1980.tb02663.x

[33] Halmer, P., Bewley, J.D. and Thorpe, T.A. (1975) Enzyme to Break Down Lettuce Endosperm Cell Wall during Gibberellin- and Light-Induced Germination. Nature, 258, 716-718. https://doi.org/10.1038/258716a0

[34] Bewley, J.D. (1997) Breaking down Walls-A Role for Endo- $\beta$-Mannase in Release from Seed Dormancy? Trends in Plant Sciences, 2, 464-469.

https://doi.org/10.1016/S1360-1385(97)01147-3

[35] Halmer, P., Bewley, J.D. and Thorpe, T.A. (1976) An Enzyme to Degrade Lettuce Endosperm Cell Walls. Appearance of a Mannanase Following Phytochrome- and Gibberellin-Induced Germination. Planta, 130, 189-196. https://doi.org/10.1007/BF00384419

[36] Halmer, P., Bewley, J.D. and Thorpe, T.A. (1978) Degradation of the Endosperm Cell Walls of Lactuca sativa L., cv. Grand Rapids. Planta, 139, 1-8. https://doi.org/10.1007/BF00390802

[37] Leung, D.W.M., Reid, J.S.G. and Bewley, J.D. (1979) Degradation of the Endosperm Cell Walls of Lactuce sativa L., cv. Grand Rapids in Relation to the Mobilisation of Proteins and the Production of Hydrolytic Enzymes in the Axis, Cotyledons and Endosperm. Planta, 146, 335-341. https://doi.org/10.1007/BF00387806

[38] Leung, D.W.M. and Bewley, J.D. (1981) Immediate Phytochrome Action in Inducting a-Galactodidase in Lettuce Seeds. Nature, 289, 587-588. 
https://doi.org/10.1038/289587a0

[39] Leung, D.W.M. and Bewley, J.D. (1981) Red-Light- and Gibberellic-Acid-Enhanced $\alpha$-Galactodidase Activity in Germinating Lettuce Seeds, cv. Grand Rapids. Planta, 152, 436-441. https://doi.org/10.1007/BF00385360

[40] Liu, C., Li, L., Chen, B. and Wang, X. (2015) Suppression of $\alpha$-L-Arabinofuranosidase in the Endosperm and Atypical Germination of Lettuce seeds Induced by Sodium Dichloroisocaynurate. Acta Physiologia Plantarum, 37, 10.

https://doi.org/10.1007/s11738-014-1761-Z

Submit or recommend next manuscript to SCIRP and we will provide best service for you:

Accepting pre-submission inquiries through Email, Facebook, LinkedIn, Twitter, etc. A wide selection of journals (inclusive of 9 subjects, more than 200 journals)

Providing 24-hour high-quality service

User-friendly online submission system

Fair and swift peer-review system

Efficient typesetting and proofreading procedure

Display of the result of downloads and visits, as well as the number of cited articles

Maximum dissemination of your research work

Submit your manuscript at: http://papersubmission.scirp.org/

Or contact ajps@scirp.org 